\title{
The Effect of Antibiotics on Synthesis of Mucopeptide and Teichoic Acid by Pediococcus cerevisiae and by a Substrain that Requires Methicillin for Growth
}

\author{
By B. J. WILKINSON* AND P. J. WHITE \\ Department of Microbiology, The University, Sheffield, SIо $2 T N$
}

SUMMARY

Mucopeptide synthesis by Pediococcus cerevisiae ATCC 808 I and P. cerevisiae CRD (a methicillin-requiring substrain) was measured by incorporation of radioactivity from ${ }^{14} \mathrm{C}$-labelled-alanine, -glutamate, -lysine and -aspartate into the mucopeptide fraction of organisms incubated in a solution inadequate to support growth. Teichoic acid synthesis was measured by incorporation of $\left[{ }^{32} \mathrm{P}^{3} \mathrm{H}_{3} \mathrm{PO}_{4}\right.$ into a hot trichloroacetic acid soluble fraction from isolated walls.

Mucopeptide synthesis by both strains (as measured by incorporation of $\left[{ }^{1-}{ }^{14} \mathrm{C}\right]$ glutamic acid) was unaffected by chloramphenicol but was sensitive to benzylpenicillin. The incorporation was resistant to methicillin in strain CRD $(2 \mathrm{mg} / \mathrm{ml}$ gave $50 \%$ inhibition) but not in parent organisms $(120 \mu \mathrm{g} / \mathrm{ml}$ gave $50 \%$ inhibition).

Strain CRD incorporated twenty times less $\left[{ }^{32} \mathrm{P}_{3} \mathrm{H}_{3} \mathrm{PO}_{4}\right.$ into teichoic acid than did the parent strain. With either strain, benzylpenicillin $(25 \mu \mathrm{g} / \mathrm{ml})$ and D-cycloserine $(200 \mu \mathrm{g} / \mathrm{ml})$ inhibited this synthesis, but methicillin $(500$ and $1000 \mu \mathrm{g} / \mathrm{ml})$ did not.

Electron micrographs of strain CRD incubated for four hours with methicillin showed large deposits of wall material around septa; these were not seen in parent organisms.

\section{INTRODUCTION}

Turbidity studies and chemical measurements showed that Pediococcus cerevisiae and $P$. cerevisiae CRD (a methicillin-requiring substrain) synthesized mucopeptide when incubated in a 'wall synthesis' solution that was inadequate for growth (Wilkinson \& White, I969). To observe the effects of antibiotics on this process more closely, especially at early stages, incorporation of radioactively labelled precursors has now been used to measure mucopeptide and teichoic acid synthesis. Walls of parent organisms contain, as well as mucopeptide, $35 \%(\mathrm{w} / \mathrm{w})$ of teichoic acid, whereas walls of strain CRD have only $16 \%(\mathrm{w} / \mathrm{w})$ teichoic acid (White, I $968 \mathrm{~b}$ ). The effects of some inhibitors of mucopeptide synthesis on teichoic acid synthesis have also been examined. A preliminary report of some of these results has been made (Wilkinson \& White, I97I).

\section{METHODS}

Organisms. The origins and methods of maintenance of Pediococcus cerevisiae strain $808 \mathrm{I}$ and substrain CRD are described by White (r968a).

Media. All media were made in distilled water and sterilized by autoclaving at $\mathrm{I} 2 \mathrm{I}{ }^{\circ} \mathrm{C}$ for I $5 \mathrm{~min}$. The partly defined medium was that of White (I968a).

Peptone + yeast extract + glucose medium (PYG) contained (g/l): Oxoid peptone, 20; Difco yeast extract, Io; and glucose, 20; the pH value was adjusted to 6.5. Peptone + yeast

* Present address: Department of Biochemistry, University of Cambridge. 
extract + glucose + acetate medium (PYGAc) was $P Y G$ plus sodium acetate trihydrate $(20 \mathrm{~g} / \mathrm{l})$. The $\mathrm{pH}$ value was adjusted to $6 \cdot 5$.

Conditions of growth. One litre of PYGAc medium (in a 21 conical flask) was inoculated with $10 \mathrm{ml}$ of an overnight culture of organisms (strain 808I) grown in partly defined medium. Strain CRD was grown by inoculating $\mathrm{I} 1$ of PYGAc + methicillin $(100 \mu \mathrm{g} / \mathrm{ml})$ with I $\mathrm{ml}$ of a $24 \mathrm{~h}$ culture grown in partly defined medium + methicillin $(100 \mu \mathrm{g} / \mathrm{ml})$. The flasks were incubated standing at $37{ }^{\circ} \mathrm{C}$ until the mid-exponential phase of growth was reached. This was after parent organisms had been incubated for about $8 \mathrm{~h}$ and had attained a reading of $I \cdot 2$ to $I .8$ (in $\frac{1}{4}$ in diameter tubes) in the EEL colorimeter with neutral density no. I $\cdot 0$ filter (Evans Electroselenium Co. Ltd, Halstead, Essex) against a zero of distilled water. Strain CRD was grown for 26 to $30 \mathrm{~h}$ before harvesting. The organisms were harvested by centrifuging at $5000 \mathrm{~g}$ for $5 \mathrm{~min}$ at $2{ }^{\circ} \mathrm{C}$ and washed once in distilled water.

Solutions for study of wall synthesis. Solution WIoo contained (g/l): $\mathrm{KH}_{2} \mathrm{PO}_{4}$ (adjusted to $\mathrm{pH} 6.5$ with $5 \mathrm{~N}-\mathrm{NaOH})$, I3.6; glucose, I.8; $\left(\mathrm{NH}_{4}\right)_{2} \mathrm{SO}_{4}, \mathrm{I} ; \mathrm{MgSO}_{4} \cdot 7 \mathrm{H}_{2} \mathrm{O}, 0.2$; L-lysine, 0.002 ; L-aspartate, 0.002 ; L-glutamate, 0.002 ; L-alanine, 0.004. Solution WT (for studies of teichoic acid synthesis) was solution Wroo with most of the phosphate buffer replaced by O.I M-maleate- $\mathrm{NaOH}$ buffer, $\mathrm{pH} 6.5$, and only a substrate amount of $\mathrm{KH}_{2} \mathrm{PO}_{4}(2 \mu \mathrm{g} / \mathrm{ml})$ included.

Isolation of walls and mucopeptide. Mucopeptide was isolated by the method of Park \& Hancock (I960) modified by including a wash in water after treatment with hot trichloroacetic acid, TCA (otherwise the trypsin was inactivated) and by raising the concentration of trypsin to $100 \mu \mathrm{g} / \mathrm{ml}$. The mucopeptide residue was finally washed in water to remove trypsin and hydrolysis products. Walls were prepared as described by White (I968b) except that the organisms were broken at $2{ }^{\circ} \mathrm{C}$ in a Mickle (1948) tissue disintegrator.

Measurement of mucopeptide synthesis. Washed organisms were suspended in a volume of water such that when $\mathrm{IO} \mathrm{ml}$ of this suspension was added to $50 \mathrm{ml}$ of solution WIOO (at $\mathrm{I} \cdot 2 \times$ strength, pre-incubated at $37^{\circ} \mathrm{C}$ in a conical flask) the final bacterial concentration was 0.3 to $0.4 \mathrm{mg}$ dry $\mathrm{wt} / \mathrm{ml}$. One $\mu \mathrm{Ci}$ of the ${ }^{14} \mathrm{C}$-labelled amino acid was included in solution Wroo (60 $\mathrm{ml}$ final volume in a $100 \mathrm{ml}$ flask). The $E_{610 \mathrm{~nm}}$ of the suspension was measured after dilution ( $\mathrm{I} \mathrm{ml}+5 \mathrm{ml}$ of water) at the beginning of the experiment; duplicate $5 \mathrm{ml}$ samples of suspension were taken at intervals during the incubation and mixed with I $\mathrm{ml}$ of $30 \%(\mathrm{w} / \mathrm{v}) \mathrm{TCA}$ at $2{ }^{\circ} \mathrm{C}$ in a test tube. The tubes were stored at $2{ }^{\circ} \mathrm{C}$ before the mucopeptide was isolated as described above and its radioactivity measured after resuspension in scintillation fluid.

Measurement of teichoic acid synthesis. Organisms were grown, harvested, washed and resuspended in solution WT $(0.3$ to $0.4 \mathrm{mg}$ dry wt of organisms $/ \mathrm{ml})$. The suspension $(420 \mathrm{ml}$ in a 1 flask) plus $50 \mu \mathrm{Ci}$ of $\left[{ }^{32} \mathrm{P}\right] \mathrm{H}_{3} \mathrm{PO}_{4}$ was incubated at $37{ }^{\circ} \mathrm{C}$. Samples (I00 or $200 \mathrm{ml}$ ) were taken at intervals, centrifuged, washed and stored overnight as a pad at $-15{ }^{\circ} \mathrm{C}$. Walls were prepared and samples $(0 . \mathrm{I} \mathrm{ml})$ of the wall after suspension in water $(2 \mathrm{ml})$ were removed for estimation of radioactivity. The $E_{610 \mathrm{~nm}}$ of the suspension of walls was measured and their weight assessed by comparison with a calibration curve. The walls were centrifuged (I5000 $\mathrm{g}$ for I $5 \mathrm{~min}$ ) and resuspended in $2 \mathrm{ml} \mathrm{TCA} \mathrm{(10 \% ,w/v)} \mathrm{then} \mathrm{heated} \mathrm{at} 60{ }^{\circ} \mathrm{C}$ for 90 min (Boylen \& Ensign, 1968). After removing the solid residue by centrifuging, samples $(0.1 \mathrm{ml})$ of the extracted walls that had been resuspended in water $(2 \mathrm{ml})$ were also counted. The phosphorus content of the TCA extract was measured as described below.

Measurement of radioactivity. All samples were counted in a Nuclear-Chicago coincidence liquid scintillation spectrometer (model 680I, Nuclear-Chicago Corporation, Des Plaines, Illinois, U.S.A.). With ${ }^{14} \mathrm{C}$, efficiency of counting was calculated using the channels ratio 
method (Nuclear-Chicago Liquid Scintillation Manual, 1965). An efficiency of $55 \%$ for ${ }^{32} \mathrm{P}$-counting was determined by counting $\mathrm{O} \cdot \mathrm{I} \mu \mathrm{Ci}$ of $\left[{ }^{32} \mathrm{P}\right] \mathrm{H}_{3} \mathrm{PO}_{4}$ and assuming the information supplied on the strength of the isotope to be correct.

The scintillation fluid was N.E. 220 (Nuclear Enterprises Ltd, Sighthill, Edinburgh I I) or an equivalent fluid prepared in the laboratory by adding $7 \mathrm{~g}$ of 2,5-diphenyloxazole, $0.3 \mathrm{~g}$ of $p$-bis-2-(5-phenyloxazoyl)-benzene and $100 \mathrm{~g}$ of naphthalene to $\mathrm{I} 1$ of dioxan and stirring for several hours.

Autoradiography. Chromatograms were put in contact with Kodirex X-ray film (Kodak Ltd) for five weeks before development. Amino acids were located by ninhydrin treatment of the chromatogram and the positions of fogged areas of film were compared.

Estimation of phosphorus. The samples for phosphorus determination contained $10 \%$ $(\mathrm{w} / \mathrm{v})$ TCA, and were ashed to convert organic $\mathbf{P}$ to inorganic $\mathbf{P}$ before estimation, as described by Leloir \& Gardini (1957). A calibration curve was prepared with $\mathrm{I} \cdot 0 \mathrm{mM}$-glucose 6-phosphate di-sodium salt in $10 \%(\mathrm{w} / \mathrm{v})$ TCA.

Electron microscopy. The following procedures were carried out by Mrs M. Haynes of the Biochemistry Department, University of Sheffield.

Organisms were washed in water before being fixed in a $2.5 \%(\mathrm{v} / \mathrm{v})$ solution of glutaraldehyde in $0 . \mathrm{I} \mathrm{M}$-phosphate buffer, $\mathrm{pH} 7 \cdot 2$, for $2 \mathrm{~h}$ at $2{ }^{\circ} \mathrm{C}$. They were transferred to a $7.5 \%$ (w/v) solution of sucrose in $0 \cdot \mathrm{I}$ M-phosphate buffer, $\mathrm{pH} 7 \cdot 2$, for overnight washing at $2{ }^{\circ} \mathrm{C}$ and were then post-fixed in $\mathrm{I} \%(\mathrm{w} / \mathrm{v}) \mathrm{OsO}_{4}$ for $0.5 \mathrm{~h}$ at room temperature. The organisms were dehydrated, after washing in water for $5 \mathrm{~min}$, by passing through the following concentrations of ethanol in water (each v/v): $50 \%, 75 \%, 95 \%, 100 \%$ (twice), and dry absolute ethanol; they remained in each solution for $10 \mathrm{~min}$. The organisms were embedded in dry absolute ethanol + epon $(\mathrm{I}+\mathrm{I}, \mathrm{v} / \mathrm{v})$ for $2 \mathrm{~h}$ and then transferred to fresh epon at $60{ }^{\circ} \mathrm{C}$ for $48 \mathrm{~h}$. The capsules were removed with boiling water and the blocks trimmed with a razor blade. Sections 60 to $90 \mathrm{~nm}$ thick were cut with an ultramicrotome and stained with lead citrate (Reynolds, I963) before being examined in an A.E.I. EM6B electron microscope (Associated Electrical Industries Ltd, I Stanhope Gate, London W. I).

Chemicals. Radioisotopes were obtained from the Radiochemical Centre, Amersham, Buckinghamshire. D-Cycloserine was obtained from Sigma Chemical Co., St Louis, Missouri, U.S.A. Benzylpenicillin and methicillin were from Beecham Research Laboratories, Betchworth, Surrey. Chloramphenicol was a gift (to Dr B. A. Fry) from Parke Davis Co., Hounslow, Middlesex.

\section{RESULTS}

The effects of benzylpenicillin, methicillin and other antibiotics on the incorporation of amino acids into the mucopeptides of Pediococcus cerevisiae and P. cerevisiae CRD

Hancock \& Park (1958) and Mandelstam \& Rogers (1959) have shown that the incorporation of labelled amino acids into the mucopeptide of Staphylococcus aureus was sensitive to benzylpenicillin but resistant to chloramphenicol. In Pediococcus cerevisiae 808 I incorporation of $\left[\mathrm{I}^{-14} \mathrm{C}\right] \mathrm{glutamic}$ acid was almost entirely abolished by benzylpenicillin $(25 \mu \mathrm{g} / \mathrm{ml})$; incorporation in the presence of chloramphenicol $(100 \mu \mathrm{g} / \mathrm{ml})$ was indistinguishable from incorporation in the absence of any antibiotic, while methicillin $(200 \mu \mathrm{g} / \mathrm{ml})$ caused substantial inhibition (Fig. I $a$ ). Strain CRD was sensitive to benzylpenicillin but less sensitive to methicillin (Fig. $\mathrm{I} b$ ) than the parent strain. The amounts of $\left[\mathrm{I}^{14} \mathrm{C}\right]$ glutamic acid incorporated by strain CRD ( $25 \mathrm{nmol} / \mathrm{mg}$ dry wt) and parent ( $2 \mathrm{nmol} / \mathrm{mg}$ dry $\mathrm{wt}$ ) are typical values. The concentration of methicillin required to inhibit mucopeptide synthesis in parent and strain CRD grown in the presence and absence of methicillin were measured (Table I). With the 

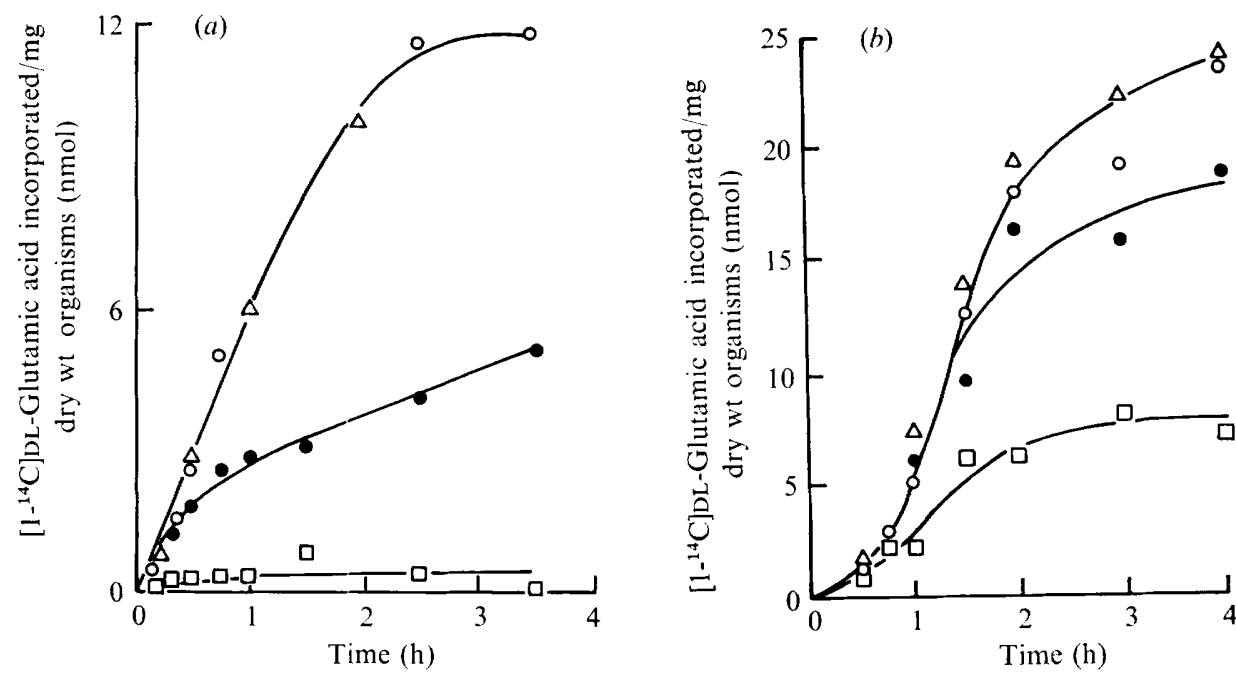

Fig. I. Effect of chloramphenicol, methicillin and benzylpenicillin on the incorporation of $\left[\mathrm{I}^{\left.\mathbf{~}{ }^{\mathbf{1 4}} \mathrm{C}\right] \mathrm{DL}-}\right.$ glutamic acid into the mucopeptide of $(a)$ parent strain, $(b)$ strain CRD. The organisms were grown in (a) PYGAc medium, or (b) PYG medium, harvested, washed and resuspended $(0.3$ to $0.4 \mathrm{mg}$ dry $\mathrm{wt} / \mathrm{ml})$ in solution $\mathrm{W}_{100}$ containing $\mathrm{I} \mu \mathrm{Ci}$ of $\left[\mathrm{I}^{14} \mathrm{C}\right] \mathrm{DL}$-glutamic acid. $-\mathrm{O}-$, No antibiotic;

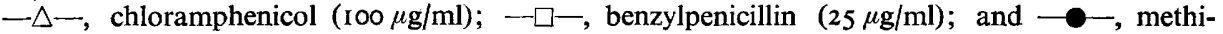
cillin $(200 \mu \mathrm{g} / \mathrm{ml})$. The flasks were incubated standing at $37^{\circ} \mathrm{C}$ and samples were taken at intervals for isolation of mucopeptide and subsequent measurement of radioactivity.

\section{Table $\mathrm{I}$. Inhibition of incorporation of $\left[\mathrm{I}-{ }^{14} \mathrm{C}\right]$ glutamic acid into} mucopeptides by benzylpenicillin and methicillin

Exponential phase organisms were harvested from the media indicated, washed and resuspended $(0.3$ to $0.4 \mathrm{mg}$ dry $\mathrm{wt} / \mathrm{ml})$ in solution WIOO in flasks containing various concentrations of penicillins. The flasks were incubated standing at $37^{\circ} \mathrm{C}$ and samples were taken at intervals for isolation of mucopeptide and measurement of its radioactivity.

\begin{tabular}{|c|c|c|c|c|}
\hline & & \multicolumn{3}{|c|}{ Inhibition (\%) after $3 \mathrm{~h}$ of: } \\
\hline & \multirow[b]{2}{*}{$\begin{array}{c}\text { Concentration } \\
(\mu \mathrm{g} / \mathrm{ml})\end{array}$} & & \multicolumn{2}{|c|}{ CRD } \\
\hline & & $\begin{array}{l}\text { Parent } \\
\text { grown in } \\
\text { PYGAc }\end{array}$ & $\begin{array}{l}\text { Grown in } \\
\text { PYG }\end{array}$ & $\begin{array}{l}\text { Grown in } \\
\text { PYGAc+ } \\
\text { methicillin } \\
(100 \mu \mathrm{g} / \mathrm{ml})\end{array}$ \\
\hline \multirow[t]{2}{*}{ Benzylpenicillin } & $2 \cdot 5$ & 48 & - & - \\
\hline & 25 & 96 & $7 \mathrm{I}$ & 一 \\
\hline \multirow[t]{7}{*}{ Methicillin } & 50 & 34 & - & - \\
\hline & 100 & 一 & IO & 34 \\
\hline & 200 & 56 & $2 I$ & - \\
\hline & 250 & 72 & - & 一 \\
\hline & 500 & 87 & 31 & 40 \\
\hline & 1000 & 94 & 37 & 50 \\
\hline & 3000 & - & 56 & 56 \\
\hline
\end{tabular}

parent strain, relatively low concentrations of methicillin were inhibitory: an effect of the drug was seen after $30 \mathrm{~min}$ with $50 \mu \mathrm{g} / \mathrm{ml}$, after $20 \mathrm{~min}$ with $250 \mu \mathrm{g} / \mathrm{ml}$, in less than Io min with $500 \mu \mathrm{g} / \mathrm{ml}$ or I $\mathrm{mg} / \mathrm{ml}$. Mucopeptide synthesis in strain CRD (grown in PYG medium without methicillin) was resistant to methicillin; $3 \mathrm{mg} / \mathrm{ml}$ caused only about $50 \%$ inhibition and $500 \mu \mathrm{g} / \mathrm{ml}$ only began to have a noticeable effect after about $50 \mathrm{~min}$. When strain CRD was grown in PYGAc medium in the presence of methicillin the incorporation of $\left[\mathrm{I}-{ }^{14} \mathrm{C}\right]-$ 




Fig. 2. Effect of methicillin on the incorporation of $\left[\mathrm{I}^{14} \mathrm{C}\right] \mathrm{DL}-\mathrm{glutamic}$ acid into the mucopeptide of strain CRD previously grown in the presence of antibiotic, i.e. in PYGAc medium plus methicillin $(100 \mu \mathrm{g} / \mathrm{ml})$. A series of flasks with different antibiotic concentrations was set up as in Fig. I. $-\mathrm{O}-$, No antibiotic; $-\triangle-$, +methicillin $(100 \mu \mathrm{g} / \mathrm{ml}) ;-\square-$, + methicillin $(500 \mu \mathrm{g} / \mathrm{ml})$; - - + methicillin $(\mathrm{I} \mathrm{mg} / \mathrm{ml}) ;-\mathbf{A}-,+$ methicillin $(3 \mathrm{mg} / \mathrm{ml})$.

Table 2. The incorporation of ${ }^{14} \mathrm{C}$-labelled amino acids into the mucopeptides of parent and strain $\mathrm{CRD}$

Parent organisms were grown in PYGAc and strain CRD grown in PYG. Five flasks were set up for each strain, each containing $\mathrm{I} \mu \mathrm{Ci}$ of the ${ }^{14} \mathrm{C}$-labelled amino acid indicated. The flasks were incubated at $37^{\circ} \mathrm{C}$. Cold carrier L-phenylalanine $(10 \mu \mathrm{g} / \mathrm{ml})$ was included in the $\left[{ }^{14} \mathrm{C}\right]$ phenylalanine containing flask.

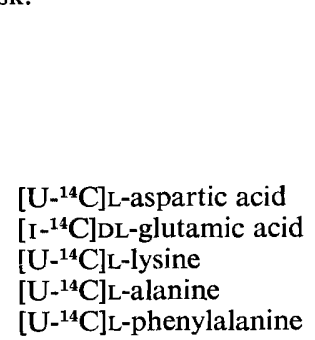

$\overbrace{\text { Parent }}^{\begin{array}{c}\text { nmol Amino acid } \\ \text { incorporated/mg dry wt of } \\ \text { organisms in } 2 \frac{1}{2} \mathrm{~h}\end{array}} \begin{gathered}\text { Strain CRD } \\ \text { 10 }\end{gathered}$

glutamic acid in $3 \mathrm{~h}$ was less than half that of organisms grown in PYG medium without methicillin (Fig. 2). Mucopeptide synthesis in CRD organisms grown with methicillin present was still highly resistant to methicillin, although not as resistant as that of organisms grown in the absence of the drug. Growth with methicillin may facilitate the uptake of methicillin or expose methicillin binding sites, or may partly saturate a sensitive enzyme system.

The four component amino acids were incorporated into mucopeptide but phenylalanine, which is absent from the mucopeptide, was not, indicating that the method for isolation gives a mucopeptide uncontaminated with protein (Table 2). From the analysis of mucopeptide, one mole of glutamate, one of lysine and one of aspartate might be expected to be incorporated for every two moles of alanine. The parent strain incorporated alanine in large amounts although not in twice the molar amounts of all the other amino acids. There was a high incorporation of lysine in both strains, and strain CRD incorporated relatively 
Table 3. Effect of methicillin on the incorporation of $\left[{ }^{32} P\right]$ phosphate into the hot TCA soluble fraction of the walls of Pediococcus cerevisiae and Pediococcus ceresiviae CRD

Parent organisms were grown in PYGAc, and strain CRD grown in PYG. Washed organisms were incubated in solution WT at $37^{\circ} \mathrm{C}$. Samples $(100 \mathrm{ml})$ were taken at intervals and walls isolated and treated as described in Methods.

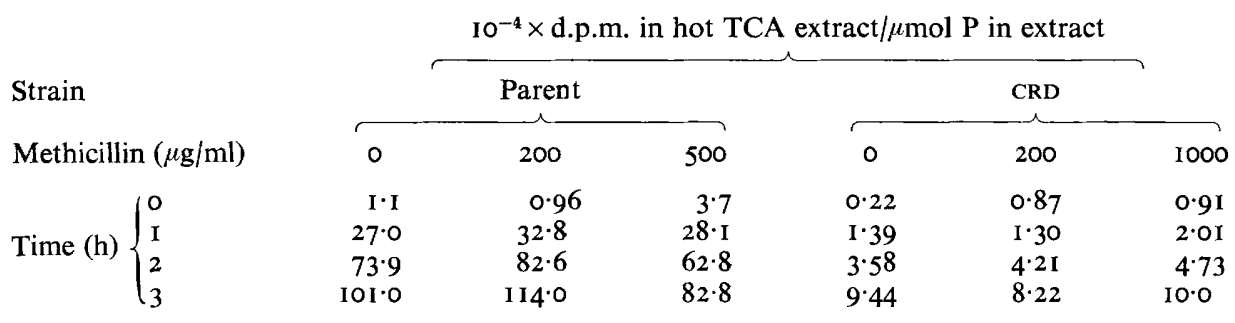

more glutamate than the parent. This pattern of incorporation may be affected by the level of unlabelled pool amino acids since Holden (1962) showed generally high levels of endogenous glutamate and low levels of lysine in a number of bacterial species. Aspartic acid was incorporated in substantial quantities, even though it was not required to produce a turbidity increment (Wilkinson \& White, 1969).

Autoradiography of the hydrolysed mucopeptides showed only one fogged area of film corresponding to the radioactively labelled amino acid supplied.

Teichoic acid synthesis by parent and strain CRD. These were compared (Table 3). The results are expressed as specific activities because the amounts of walls obtained varied. Typically, about $\mathrm{I} \cdot 7$ and $0.3 \mu \mathrm{mol}$ of $\mathrm{P}$ were extracted from I mg of walls from parent and strain CRD respectively. This difference in $P$ content between parent and strain CRD is rather more than that found in previous experiments using partially defined media (White, I968 $b$ ). Possibly the difference in $\mathbf{P}$ content of the walls of the organisms is more marked when they are grown on crude media. $\left[{ }^{32} \mathrm{P}\right]$ was incorporated into hot TCA extractable material during the $3 \mathrm{~h}$ incubation period though the time course of incorporation was not linear (Table 3 ). The most striking feature was that strain CRD incorporated about 20 times less ${ }^{32} \mathrm{P}$ than did parent organisms. Approximately io $\mathrm{nmol}$ of phosphate were incorporated (from solution WT) by I mg of parent organism in $3 \mathrm{~h}$ whereas only $0.5 \mathrm{nmol}$ of phosphate was incorporated/mg of strain CRD in the same time. These values may be compared with the incorporation of a typical amino acid (from solution $\mathrm{W}_{\mathrm{IOO}}$ ) into the mucopeptide, e.g. I 2 and $25 \mathrm{nmol}$ of $\left[{ }^{14} \mathrm{C}\right]$ glutamic acid incorporated into the mucopeptides of parent and strain CRD respectively/mg of organism in $3 \mathrm{~h}$. There was no loss of phosphorus from the walls of either strain as the ratio of phosphorus to weight of wall remained relatively constant.

D-Cycloserine $(200 \mu \mathrm{g} / \mathrm{ml})$ inhibited ${ }^{32} \mathrm{P}$ incorporation by $85 \%$ in parent organisms, and by $67 \%$ in strain CRD. Benzylpenicillin $(25 \mu \mathrm{g} / \mathrm{ml})$ inhibited incorporation by parent strain by $56 \%$ and strain CRD by $29 \%$. Both these inhibitors had less effect on teichoic acid synthesis than on mucopeptide synthesis at the same concentrations. It was surprising to find that methicillin, at concentrations high enough to give substantial inhibition of mucopeptide synthesis, had little effect on ${ }^{32} \mathrm{P}$ incorporation by parent or strain CRD (Table 3 ).

Effect of methicillin on septum formation. Electron microphotographs of organisms incubated in solution WIOO for $4 \mathrm{~h}$ and organisms suspended in solution WIoo and immediately processed (zero time control) showed wall and membrane and ingrowing septa (Fig. $3 a, b, d$ and $e$ ). When methicillin ( $\mathrm{I} \mathrm{mg} / \mathrm{ml}$ ) was present during incubation of strain CRD large deposits of wall material accumulated (Fig. $3 f$ ). This concentration of methicillin was 

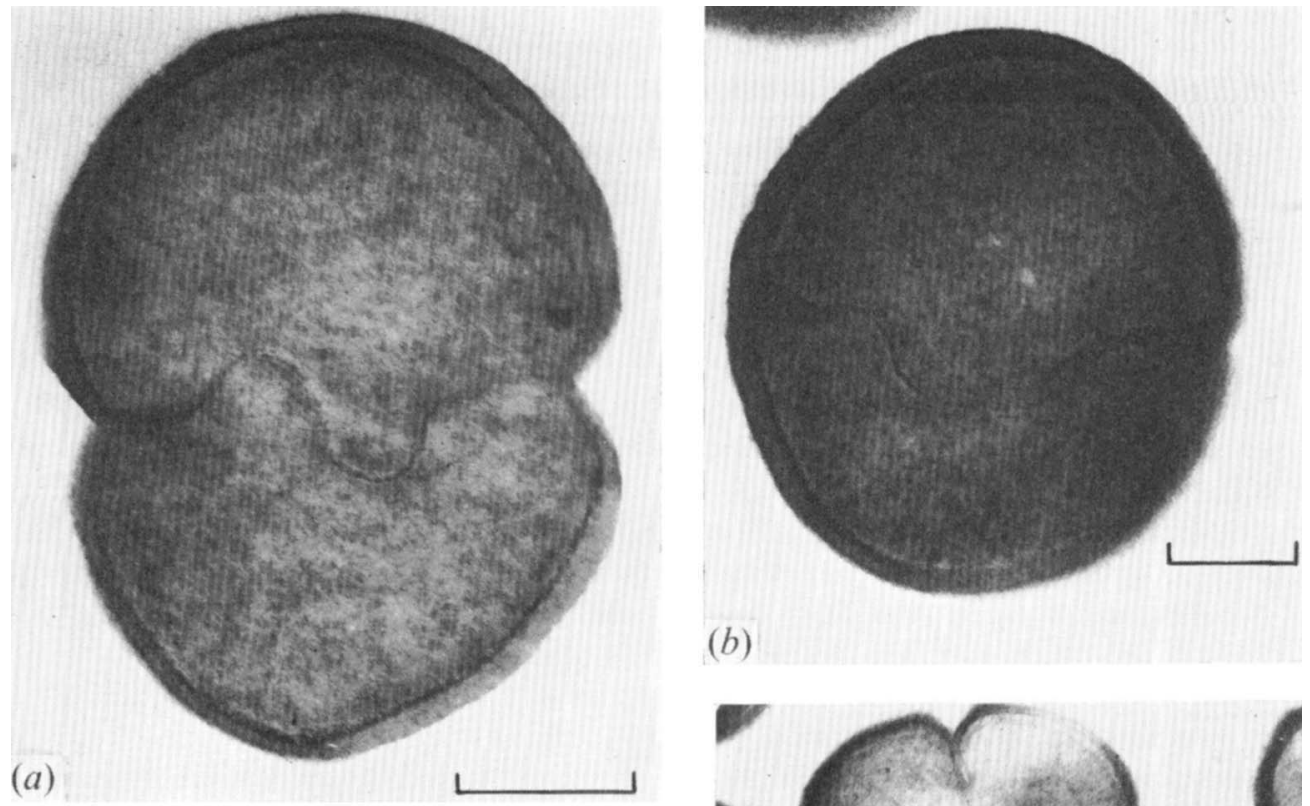

(b)
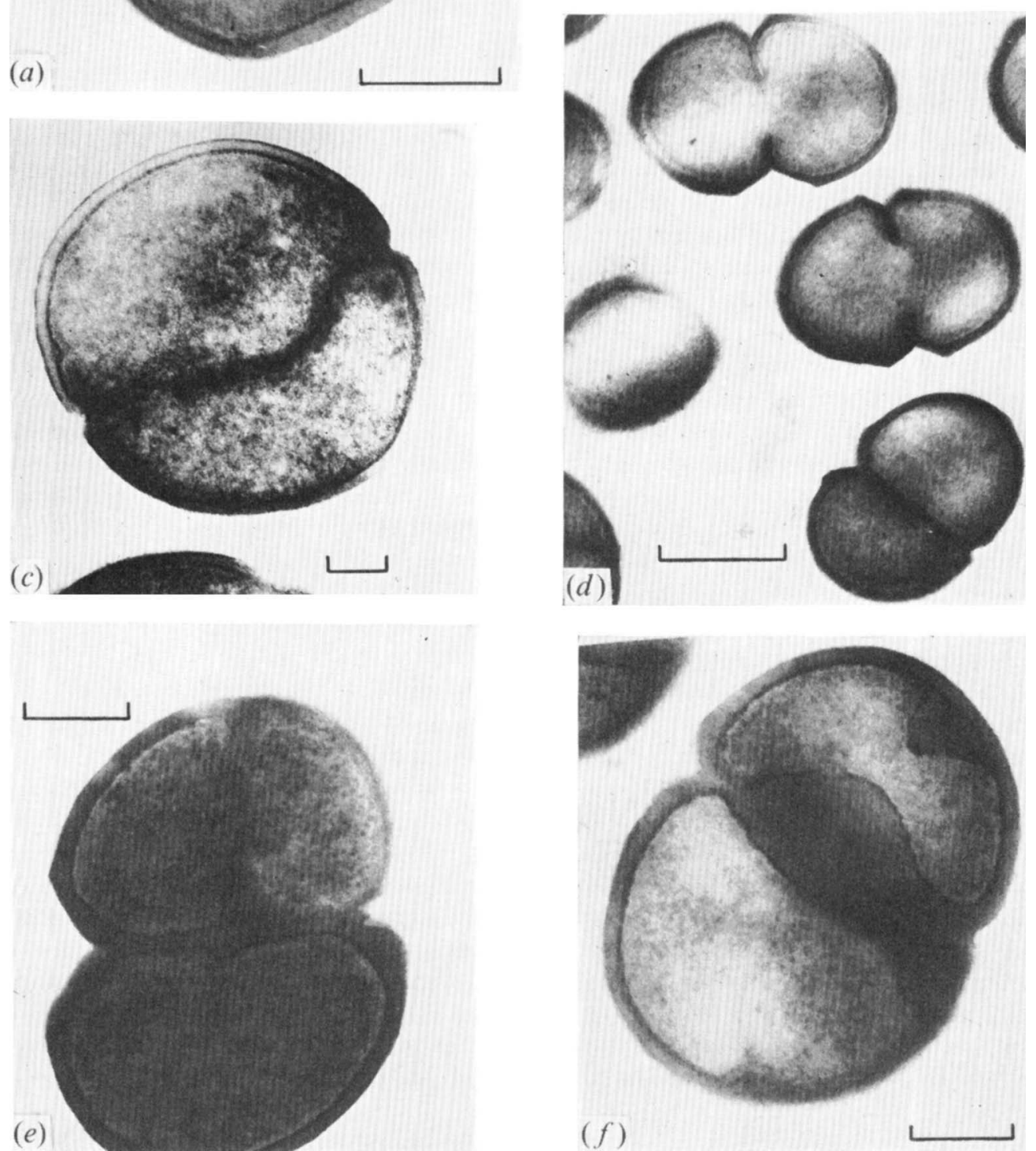

Fig. 3. Parent organism (grown in PYGAc) incubated for $(a) \mathrm{o} \mathrm{h}$ and $(b) 4 \mathrm{~h}$ at $37^{\circ} \mathrm{C}$ in solution W $100 ;$ bar $=200 \mathrm{~nm}$. $(b)$, plus methicillin $(50 \mu \mathrm{g} / \mathrm{ml}) ; \mathrm{bar}=100 \mathrm{~nm}$. Strain CRD organisms (grown in PYG) incubated for $(d)$ o h $(\mathrm{bar}=500 \mathrm{~nm})$ and $(e) 4 \mathrm{~h}(\mathrm{bar}=200 \mathrm{~nm})$ at $37^{\circ} \mathrm{C}$ in solution Wroo; $(f)$ As $(e)$ plus methicillin $(\mathrm{I} \mathrm{mg} / \mathrm{ml}) ; \mathrm{bar}=200 \mathrm{~nm}$. 
chosen because it gives about the same percentage inhibition of glutamate incorporation as does $50 \mu \mathrm{g} / \mathrm{ml}$ in the parent strain (Table I). No such deposits could be seen in the parent strain incubated in the presence of $50 \mu \mathrm{g}$ of methicillin $/ \mathrm{ml}$ (Fig. $3 \mathrm{c}$ ).

\section{DISCUSSION}

Chemical measurements have shown previously that the mucopeptide content of organisms incubated in solution W (i.e. W I00 with concentrations of amino acids raised roo-fold) increases without protein synthesis (Wilkinson \& White, 1969). Mucopeptide synthesis has now been measured by incorporation of radioactivity from ${ }^{14} \mathrm{C}$-labelled amino acids. This incorporation seems to represent mucopeptide synthesis because all the four amino acids found in the mucopeptide were incorporated in substantial amounts, whereas phenylalanine, an amino acid not found in the wall, was hardly incorporated at all.

The incorporation of $\left[{ }^{14} \mathrm{C}\right]$ glutamic acid into mucopeptide was inhibited by benzylpenicillin and methicillin but not by chloramphenicol, as was expected. About $5 \mu \mathrm{g}$ of benzylpenicillin $/ \mathrm{ml}$ and I $20 \mu \mathrm{g}$ of methicillin $/ \mathrm{ml}$ inhibited mucopeptide synthesis by $50 \%$ in the parent strain. These are about ten times the minimum inhibitory concentrations measured using small inocula (White, I968a). This may be due to new sites for penicillin fixation becoming available on the membrane (Rogers, 1970), or to appreciable mucopeptide synthesis by washed suspensions of organisms before an inhibitory concentration of penicillin has accumulated in the organisms.

The most striking difference between mucopeptide synthesis by parent and strain CRD was the resistance of the process to methicillin in strain CRD, yet the organism was only slightly less susceptible to benzylpenicillin than the parent organisms.

Teichoic acid synthesis has been measured by incorporation of $\mathrm{H}_{3}\left[{ }^{32} \mathrm{P}\right] \mathrm{O}_{4}$ into a fraction of isolated walls that is soluble in hot trichloroacetic acid (as is teichoic acid). Teichoic acid is the major if not the only phosphate-containing polymer in the walls of Pediococcus cerevisiae (White, $\mathrm{I} 968 \mathrm{~b}$ ). The low incorporation of $\left[{ }^{32} \mathrm{P}^{2} \mathrm{H}_{3} \mathrm{PO}_{4}\right.$ by strain CRD implies that it has a less active teichoic acid synthesizing system and may explain the lower proportion of this polymer in the walls of this organism. Mucopeptide and teichoic acid are synthesized co-ordinately (Rogers, I970; Boylen \& Ensign, 1968) and the inhibition of teichoic acid synthesis by benzylpenicillin and cycloserine is in accord with this. It is difficult to explain why methicillin (in high concentrations) does not inhibit teichoic acid synthesis but it may be a further instance of differences between methicillin and other penicillins (Rogers \& Jeljaszewicz, 196I; Izaki, Matsuhashi \& Strominger, I966).

If the parent organism contains very roughly $500 \mathrm{nmol}$ of mucopeptide monomer (mol. wt about I000) per mg dry wt of walls (White, I968 b) and $50 \mathrm{nmol}$ of mucopeptide monomer is synthesized per $\mathrm{mg}$ of wall in $\mathrm{I} 50 \mathrm{~min}$ (Table 2 ; wall is about $20 \%$ of dry wt of organisms) then approximately Io \% thickening of the wall during the incubation would be expected. This is difficult to detect on the electron micrographs. They do however provide evidence that new wall was not laid down all in one place. Few mesosomes were seen in electron micrographs of Pediococcus cerevisiae although a 'wavy' membrane connecting newly formed septa was often seen. The significance of this structure is not known, it may represent a kind of mesosome structure. Electron micrographs of strain CRD incubated with methicillin revealed large deposits of wall material around forming septa. Similar deposits were not seen in parent organisms incubated with methicillin. Large depositions of wall material induced by penicillin at ends and septal sites have been observed in two Gram-positive rods (Fitz-James \& Hancock, 1965; Highton \& Hobbs, 1971). 
Strain CRD shows certain features similar to some penicillin resistant mutants of Staphylococcus aureus described by Park, Griffith \& Stevenson (197I). It did not produce penicillinase, it contained more mucopeptide per organism than its parent strain (White, $1968 \mathrm{~b}$ ) and it formed mucopeptide at double the rate of the parent strain. It bound penicillin as well as the parent strain (Widdowson \& White, 197I). Park et al. (197I) have suggested that the mucopeptide transpeptidase in the septal region of their mutants is prevented from reacting with penicillin, perhaps by sealing off or being flooded with substrate, rather than modification of the penicillin sensitive transpeptidase. Mucopeptide synthesis by strain CRD (previously grown in PYG) was only inhibited $37 \%$ by methicillin (I mg/ml) (Table I). The electron micrographs show that the antibiotic inhibited synthesis of mucopeptide except at the septum. This implies an insensitivity of the transpeptidase in the septal region towards methicillin.

It is possible that strain CRD has defective autolytic enzymes causing mucopeptide synthesis to be rapid. In the absence of methicillin this would lead to wall-encased organisms. The presence of methicillin may be required to slow mucopeptide synthesis to enable insertion of new pieces of wall material. Many penicillin derivatives can support the growth of strain CRD (White, I968a) but methicillin is best, possibly because of its lack of effect on teichoic acid synthesis. There is slight evidence for less active lytic enzymes in strain CRD (Wilkinson \& White, unpublished). A number of workers have observed a correlation between teichoic acid defects and susceptibility to lysis. The specific autolytic activity of a Staphylococcus aureus mutant lacking teichoic acid was lower than the wild type (Chatterjee, Mirelman, Singer \& Park, 1969). Strains of Pneumococcus with the choline component of the teichoic acid replaced by ethanolamine became resistant to autolysin and tolerant to penicillin and cycloserine (Tomasz, Albine \& Zanati, 1970). The walls of a teichoic acid deficient mutant of Bacillus subtilis autolysed less readily than the parent strain (Van Heijenoort et al. 197I). Strain CRD walls contain less teichoic acid than the parent strain (White, I $968 b$ ) and the organisms have now been found to synthesize teichoic acid less quickly than the parent strain. These observations are consistent with strain CRD having less active autolytic enzymes.

We are grateful to Mrs M. Haynes for the electron microscopy. A Medical Research Council training scholarship was held by B.J.W. at the time of this work.

\section{REFERENCES}

Boylen, C. W. \& Ensign, J. C. (I968). Ratio of teichoic acid and peptidoglycan in cell walls of Bacillus subtilis following spore germination and during vegetative outgrowth. Journal of Bacteriology $\mathbf{9 6}$, $42 \mathrm{I}-427$.

Chatter.ee, A. N., Mirelman, D., Singer, H. J. \& Park, J. T. (1969). Properties of a novel pleiotropic bacteriophage-resistant mutant of Staphylococcus aureus H. Journal of Bacteriology 100, 846-853.

Fitz-James, P. C. \& HaNCOCK, R. (1965). The initial structural lesion of penicillin action in Bacillus megaterium. Journal of Cell Biology 26, 657-667.

Hancock, R. \& PARK, J. T. (I958). Cell wall synthesis by Staphylococcus aureus in the presence of chloramphenicol. Nature, London r8r, 1050-1052.

Highton, P. J. \& HobBs, D. G. (I971). Penicillin and cell wall synthesis: a study of Bacillus licheniformis by electron microscopy. Journal of Bacteriology 106, 646-658.

Holden, J. T. (I962). In Amino Acid Pools, p. 73. Edited by J. T. Holden. New York : Elsevier Publishing Co.

IZaki, K., Matsuhashi, M. \& Strominger, J. L. ( I 966). Glycopeptide transpeptidase and D-alanine carboxypeptidase: penicillin sensitive enzymatic reactions. Proceedings of the National Academy of Sciences U.S.A. 55, 656-663. 
Leloir, L. F. \& Gardini, C. E. (1957). Characterization of phosphorus compounds by acid lability. Methods in Enzymology 3, 840-850.

Mandelstam, J. \& Rogers, H. J. (I959). The incorporation of amino acids into the cell wall mucopeptide of staphylococci and the effect of antibiotics on the process. Biochemical Journal 72, 654-662.

Park, J. T., Griffith, M. E. \& Stevenson, I. (I97I). Resistance to penicillin in a penicillinase negative organism. Journal of Bacteriology I08, I $154-1160$.

PARK, J. T. \& HANCock, R. (1960). A fractionation procedure for studies of the synthesis of cell wall mucopeptides and of other polymers in cells of Staphylococcus aureus. Journal of General Microbiology 22, 249-258.

REYNOLDS, E. S. (1963). The use of lead citrate at high $\mathrm{pH}$ as an electron opaque stain in electron microscopy. Journal of Cell Biology 17, 208-2 I 2.

Rogers, H. J. (1970). Bacterial growth and the cell envelope. Bacteriological Reviews 34, I92-2 I4.

Rogers, H. J. \& Jeljaszewicz, J. (196I). Inhibition of the biosynthesis of cell wall mucopeptides by the penicillins. Biochemical Journal 81, 576-584.

Tomasz, A., Albine, A. \& Zanati, E. (1970). Multiple antibiotic resistance in a bacterium with a suppressed autolytic system. Nature, London 227, $138-140$.

Van Heijenoort, J., Menjon, D., Flouret, B., Szulmajster, J., Laporte, J. \& Batelier, G. (i971). Cell walls of a teichoic acid deficient mutant of Bacillus subtilis. European Journal of Biochemistry 20, $442-450$.

WhITE, P. J. (1968a). A strain of Pediococcus cerevisiae which requires methicillin for growth. Journal of General Microbiology 50, 85-105.

WhITE, P. J. (1968 b). A comparison of the cell walls of Pediococcus cerevisiae and of a substrain that requires methicillin for growth. Journal of General Microbiology 50, 107-120.

Widdowson, D. \& WhrTe, P. J. (1971). New methicillin-resistant and dependent substrains of Pediococcus cerevisiae and their uptake of benzylpenicillin. Journal of General Microbiology 66, ii.

Wilkinson, B. J. \& White, P. J. (1969). Biosynthesis of mucopeptide by Pediococcus cerevisiae and by a substrain requiring methicillin for growth. Journal of General Microbiology $\mathbf{5 7}$, xv.

Wilkinson, B. J. \& White, P. J. (197I). Teichoic acid synthesis by Pediococcus cerevisiae and $P$. cerevisiae $\mathrm{CRD}-\mathrm{a}$ substrain that requires methicillin for growth. Bacteriological Proceedings, p. 49. 